\title{
CONCERNING THE DIALECTICAL CRITICISM OF RELIGION
}

\section{Preliminary}

It has long been known that the ground on which all religions that recognize the existence of a personal God can come to an agreement, is a kind of theodicy, which here, can be understood as a defense of the belief in the existence of God. In today's world atheists are louder and braver in proclaiming their criticism of all religion. For various reasons, which I will not mention here, atheism is identified with rationalism and the names of these two worldviews are used interchangeably. Everyone who believes that the number of gods that actually exist equals zero considers himself an atheist or a rationalist. In addition, it is known that contemporary atheists evaluate all religious views in this way: as the number of gods people believe in gets closer to zero, the more rationalistic this religious view is. It would seem, then, that for this very reason monotheism is recognized as the last "bastion" of religious views, and within it - Christianity. This is the last worldview that must be criticized and completely removed so that the times of enlightened rationalism can begin. Monotheism seems to demand even more of rationalistic criticism because atheists believe that this religious superstition is most deeply rooted in Christianity, and when Christianity is defeated only atheism is possible. That is why the Christian religion will never agree with rational and critical thinking according to atheists. In other words, the defence of Christian monotheism is something like "to be or not to be" for religious structures and organizations that bring a good number of temporal profits to many. I dare to conclude that the frequent criticism of Christian monotheism in vulgar, and thus colloquial. Religious criticism can be considered an argument that, in the eyes of rationalist atheists, conveys that Christian monotheism is the most rational of all known monotheisms, and is therefore, the "Trenches of the Holy Trinity", or the last bastion of religion, behind which only the horizon of atheism extends.

The essential meaning of atheism is therefore not only a simple negation of the existence of God (this type of atheism could be called a "world view"), but it is also, and perhaps above all, a break with religion which is somehow, according to atheists, imposed and sanctioned by society. It seems that the latter meaning of atheism is emphasized today. In view of the above, the purpose of this modest article is to show the genesis and methods of the criticism of Christian theology in the context of modern atheism. 
In order to achieve what was intended, the path taken by atheistic thought from the negation of God's existence to aggressive criticism of religion, especially Christian, will be briefly outlined. Furthermore, the ways this criticism is expressed will be described along with its potential effects.

\section{From atheism to the rejection of religion}

Atheism is a complex and multifaceted phenomenon. However, there are at least three possible forms of atheism present in the thoughts of its representatives. The first one is a theoretical atheism, in other words one that is doctrinal. This typically consists of a general rejection of a worldview containing the viewpoint that recognizes the existence of God, and adopting, in its place, another worldview that no longer contains a theistic supposition. Another sort of atheism is called practical or existential atheism, or a "religion of escape". This consists in a deliberate change of one's point of view to one that does not acknowledge God's existence because of a reluctance towards this particular thesis. ${ }^{72}$ Finally, the third atheism is a view which objects entirely to theistic beliefs and is both focused and based on this opposition. ${ }^{73}$ It should be noted that these atheistic views can be arranged from the weakest to the strongest according to the strength of their criticism towards religious views or religion itself. By pointing out that the ranking presented here does not coincide with the chronological order of various types of atheistic views in the history of religious criticism, one can, at least at this point, attempt to explain the individual forms of atheism.

It happens that theoretical atheism is a phenomenon secondary to philosophy. Instead of God the atheist usually proposes another explanation for reality, for example: a materialistic one, a sensual one, liberal one, etc. Supporters of atheism refer to rational interpretation. They announce that this new worldview is inspirational, and the rejection of the existence of God is secondary and only results from the adopted worldview. The most popular version of a theoretical atheism seems to be materialism. Practical atheism is an expression of the rejection of the existence of a personal God for pragmatic or personal reasons. Practical atheists also have an attitude of conformism towards religion, which allows them to treat religion in an instrumental way, without sharing its beliefs. A few years ago, in Polish academia, Piotr Gutowski noticed that today the so-called new atheism is promoted by Richard Dawkins - publicist and evolutionist, the late Christopher Hitshens, Sam Harris and Daniel Dennett - an outstanding representative of modern philosophy of mind. ${ }^{74} \mathrm{An}$ in-depth and intelligent study of this topic can be found in the book Ateizm urojony [Imaginary Atheism] by Sławomir Zatwardnicki. ${ }^{75}$ Contemporary atheism, known as

72 See: S. Kowalczyk, Filozofia Boga, Lublin 2001, p. 19-21.

73 See: P. Gutowski, Nauki filozoficzne a nowy ateizm, [in:] Nauki przyrodnicze a nowy ateizm, M. Słomka (ed.), Lublin 2012, p. 20.

74 P. Gutowski, Nauki filozoficzne a nowy ateizm, p. 8.

75 See S. Zatwardnicki, Ateizm urojony, Kraków 2014. 
the "new" atheism, is the most offensive in its criticism of religion and devotes most of its intellectual potential of the thinkers who maintain this view. One may say that the criticism of religion is the foundation of that kind of atheism.

It seems that a contemporary criticism of the Christian religion began at the beginning of the twentieth century, when religious studies emerged as part of materialism, a popular approach at that time. It was expressed in various forms, from factual and friendly criticism through explicit debate, to aggression against religion and its followers, including criminal sanctions, as was the case in at least a few places in the world. ${ }^{76}$ Materialistic, and essentially atheistic, religious studies, by definition rejected God's existence, and therefore focused their attention on the criticism of religion. Michael Novak - the author of a book entitled No One sees $\operatorname{God}^{77}$, maintains that the "new atheism" is a set of allegations, not against God in whom atheists do not believe, but against all Christians. The new atheist, like every reasonable person, perceives injustice and innocent people suffering in the world. But the arguments of theodicy, that is, natural theology, do not convince him. He does not blame God for such a deplorable state of affairs, because he definitely rejects his existence. Rather, he blames every believer, that in the light of such overwhelming data about the world the believer is still trying to believe, or worse, to convey this faith to others. The responsibility for the evil of this world, which the old humanist atheists shifted to God's shoulders, the new atheist shifts to the Christian's shoulders. ${ }^{78}$ And here is the proper moment to focus on some of the ways atheistic criticism towards religion is presented among atheists.

Many religious scholars as well as many atheists admit that there is no objective phenomenon of religion that could be studied as a real, formal, ideal or social being, and would not be, at the same time, any specific religion. ${ }^{79}$ According to Andrzej Rusław Nowicki - one of the main representatives of Polish and Marxist Religious Studies - even the word "religion" is just an apparent name. Religion itself is simply part of culture, so its name seemingly defines some of the cultural activity of man. The dispute between atheism and religion is actually a dispute about values, because after all certain personal patterns are important in religion, which are personifications of values. ${ }^{80}$ When we talk about religion, we are really talking about people. People think that some things are sacred. They create a kind of bond with them, through which interpersonal relations are formed. In the first place a distinction ap-

76 See: M. Heller, A. Niekricz, Utopia u władzy, London 1985; T. Tindal-Robertson, Fatima, Rosja i Jan Pawet II. W jaki sposób Maryja przyczyniła się do wyzwolenia Rosji spod marksistowskiego ateizmu 13 maja 1981 - 25 grudnia 1991, Warsaw 1995; G. Górny, J. Rosikoń, Tajemnice Fatimy. Największy sekret XX wieku, Warsaw 2016, p. 144-157.

77 See: M. Novak, No One sees God. The Dark Night of Atheists and Believers, New York 2008; S. Zatwardnicki, Ateizm urojony, p. 26-30.

78 See: S. Mirari, How Dialogue is done? A Review of Michael Novak's No One sees God. The Dark Night of Atheists and Believers, "National Catholic Register" 2 (2016), p. 1-2.

79 P. Moskal, Religia i prawda, Lublin 2008, p. 37.

80 A. R. Nowicki, Zarys dziejów krytyki religii. Starożytność, Warsaw 1986, p. 25. 
pears between those who are "closer to the holy objects" and they use that relationship to impose their will on those who are "further". There is, therefore, a division of the community, which over time develops into opposition in both groups. Of course, it cannot be assumed that this division is always developed consciously or intentionally. In the rich reality of religion, it appears as various principles. In uneducated people, religious ideas are more common and widespread. Among theologians and religious philosophers, we encounter systemic beliefs that are less common than imagined. ${ }^{81}$ In addition, one must not forget that doctrine is only one of the elements of the multi-faceted phenomenon of religion. Atheists themselves, apart from feelings and beliefs, admit that there are still desires and resolutions. ${ }^{82}$ Hegelian philosophy postulated that the more complex the reality, the more definitions it can define and the more it requires the use of a pluralism of methods in research. For this reason, atheists suggest that the method of studying religion is not so much chosen, but rather created by the integration of many different methods. ${ }^{83}$ It is difficult to say that the atheist postulate has been honestly implemented in philosophy. Thinkers seeking the most appropriate method chose it rather than created it by integrating existing methods. Even Descartes did this at the critical stage of building his philosophical method ${ }^{84}$ For this reason, the question remains open as to whether the critics of religion really integrate all available methods or choose those that are compatible with their intellectual strategy, which is already a worldview rather than a scientific element. ${ }^{85}$

Even within Christian religious studies, it is believed that religion in general cannot be defined. This is because in the systematics of religion we are not dealing with divisions, but with a typology, in which the main type is one specific religion, regardless of whether it is professed or criticized. ${ }^{86} \mathrm{An}$ atheist critic of religion differs from a believing critic of religion in that the former fights all religions, and the latter - all but his own. Such an attitude would be a reduction of religion to a set of beliefs which, according to Nowicki, is not appropriate. As an example, a Polish atheist referred to Pomponantius, who claimed that either one religion is true or all of them are false. In contrast, Giordano Bruno, considered by Nowicki as a pioneer of rationalism, argued that every nation can have its own religion and every one of them will be true for that nation.$^{87}$ The multitude of views on the issue of religion is a reflection of the multi-faceted nature of this phenomenon, as maintained by the expert of logic and religion Józef Bocheński. ${ }^{88}$ The multitude of views on religion, and therefore various

81 A. R. Nowicki, Zarys dziejów, p. 21.

82 A. R. Nowicki, Zarys dziejów, p. 19.

83 A. R. Nowicki, Zarys dziejów, p. 10-13.

84 R. Descartes, Rozprawa o metodzie, Warszawa 2016, p. 16.

85 J. Wojtysiak, Filozofia i życie, Kraków 2007, p. 118.

86 P. Moskal, Religia i prawda, p. 25, 37.

87 A. R. Nowicki, Zarys dziejów, p. 34.

88 J. Bocheński, Logika religii, [in:] J. Bocheński, Dzieła zebrane, t. 6, Religia, Kraków 1995 , p. 40. 
options for approaching this issue, may in fact be positive for science, including religious studies. Thus, atheists come to the conclusion that criticism of religion cannot really be homogeneous, if only because religion is understood in various ways. In view of the above, several strategies for criticizing religion can be distinguished. They are, for example, distinguishing religion from superstition, criticizing anthropomorphism, demonstrating the existence of a deity or deities while simultaneously criticizing religion, which is a characteristic approach even for followers of deism, skepticism and agnosticism, ignoring religious content in cosmology, practicing "secular" ethics, opposing the existence of a deity or deities while altering religious content (this can be found in Homer), and ridiculing religion, which is considered as an expression of courage and substantive criticism by atheists. ${ }^{89}$ Documenting arguments against the existence of deities is also a form of religious criticism. A sort of criticism towards religion is collecting and archiving all the arguments against God's existence. Nowicki himself describes this activity as practicing "atheography". This term was allegedly adopted even in Christian environments..$^{90}$ Finally, an important kind of criticism of religion is "incontrology", i.e. the description of the meeting of people or thoughts that have resulted in an intellectual development towards atheism. ${ }^{91}$

The atheistic criticism of religion begins with a critical look at the objects of worship, here called religious objects. As for the criticism of an object of religion, its existence may be either questionable (e.g. God), or impossible to be questioned (e.g. sun). Or, it can be an object that is completely created for religion (e.g. host, relic). Such an item should be called a religious artifact. ${ }^{92}$ Looking critically at the objects of religion, the atheist may come to the conclusion that the object actually has no meaning of its own and is only a specific form of presenting an extra-religious meaning. If religious sentences are based on a premise about the existence of a supernatural world, they are either simply false or meaningless or allegorical at best, because they are really talking about the material world. Atheists recognize that the form of religion is only a secondary mystification of some non-religious content. Atheism would be a negation of this secondary form, i.e. the basic substantive condition for describing reality as a whole. According to atheists religion does not allow a description of the whole world, because putting some parts of it in religious "garments" is excluding them from the discussion and inhibiting their critical perspective. ${ }^{93}$ It should be added that, according to Nowicki, the subject of religion does not differ in essence from the subject of art. Religion would consist not only in the fact that a person believes in the existence of this object, but that it connotes it in a religious way because he feels fear or fascination for it. ${ }^{94}$

\footnotetext{
89 A. R. Nowicki, Wspótczesna filozofia włoska, Warsaw 1977, p. 114.

90 A. R. Nowicki, Zarys dziejów, p. 56.

91 A. R. Nowicki, Zarys dziejów, p. 65

92 A. R. Nowicki, Zarys dziejów, p.15.

93 A. R. Nowicki, Zarys dziejów, p. 48-49.

94 A. R. Nowicki, Zarys dziejów, p. 16-17.
} 
According to atheists, the source of religion is exclusively the human mind. That which is contained in religion is equal to that which is contained in fairy tales, that people universally believe in. Belief in the content of a fairy tale or story turns this reality into a myth. Hence, religion is not so much imagination but beliefs. Andrzej Nowicki states, in the words of Władysław Witwicki, that religion consists of suppositions that are "seemingly beliefs", that are adopted despite contradictions with true beliefs. This is especially true for enlightened people whose true beliefs are incompatible with religious ones. ${ }^{95}$ However, it turns out that according to atheists, showing the natural sources of religion does not exhaust its criticism. For example, Shakespeare's writings have their natural sources and people still read and respect them. ${ }^{96}$

Yes, showing the natural genesis of religion is sufficient to offset its rejection by rationally thinking individuals, but it is not enough to annihilate it. The dialectical method should be used for this purpose.

\section{From rejection of religion to its destruction}

Andrzej Nowicki noted that selecting the proper methods has its roots in the Renaissance. Giulio Cesare Vanini stated that science, through its study of the world using specific methods and description, is to serve the truth. However, there may be two situations in which this task is not fulfilled. These are, errors and lies. If there are irregularities in the field of cognition, or if for some reason one of the accepted methods fails, then we are dealing with an error. The reliable antidote to error is practicing science, i.e. researching, observing, experimenting, learning someone else's views and arguments, comparing them with your own and assessing them. However, there is a second opposite to truth, which is a lie based on people's interests and goals. Then there is no room for science, this is an area of politics. So, it would be the wise man's duty not to search for the truth, but to unmask the frauds and detect their lies. ${ }^{97}$ This reasoning was adopted by Marxists and applied to religion. Thus, an incorrect social order is proclaimed as a good, religion defends this good, so whoever violates religion, harms the good it defends. In this way religion surrounds itself with a lie that proclaims that her critics are striking at the good of the social order. ${ }^{98}$ Such views in the spirit of Vanini need not only be rejected, but to be combated as harmful and destroyed as soon as possible.

To achieve this goal, one cannot emphasize an absolute contradiction between criticism and defense of religion. Sometimes honest criticism of some thesis can become its defense. As an example, Nowicki speaks in this way about the criticism of religion led by Gabriel Marcel or Jean de Lacroix. Dialectical criticism, which

\footnotetext{
95 A. R. Nowicki, Uczeń Twardowskiego Władysław Witwicki, Katowice 1983, p. 34-38.

96 A. R. Nowicki, Zarys dziejów, p. 40

97 A. R. Nowicki, Vanini, Warsaw 1987, p. 45.

98 A. R. Nowicki, Zarys dziejów, p. 43.
} 
is to end with the annihilation of religion, must begin with the transfer of criticized content into other contexts, because the sense of a given content is determined by the context to which it belongs. ${ }^{99}$ For religious content, these contexts should be, in principle, non-religious. Dialectical negation is not a simple rejection. Rather, it is a combination of affirmation and negation. Through this combination, what is affirmed is "absorbed" and is annihilated in its separate being, thus becoming part of the whole through which, it was absorbed. ${ }^{100}$ It is worth looking at the genesis and operation of the dialectical method of the criticism of religion.

Its roots can be traced to nineteenth-century German idealism. One of its most prominent representatives was Georg Wilhelm Friedrich Hegel, who contributed most to the development and spread of idealism as such. Hegel maintained that the subject of knowledge in general, and the subject of Philosophy in particular, is a concept that appears as a perfect general object present in thoughts. And thus, it turns out that Philosophy is a reflection of human reason over itself. To objectify these reflections and make them possible to communicate and be understood by others, it was necessary to apply the dialectical method of using pure, logical negation of the thesis appearing in the mind of the thinking subject. This negation in some way also contains a negated thesis. Hegel believed that the logical negation symbolically written as "non-p" contains within it the proposition "p", just as the statement "non-p" contains in itself the variable letter " $p$ ". And so, the presence in one mind and in one time of both the thesis and the antithesis produces a certain kind "mental tension" allowing a creative synthesis to be achieve, which is a certain novelty and an added value in the thought process. In this way thought develops. Nowicki mentions this, citing Ugo Spirito: "Each word $[\ldots]$ is an explication of everything that is implicit in it. In the act of uttering the word, all my reality [...] lives in this word and only in it. So that the word, living whole [...] must be an absolute. Conversely, the same word, since it has been spoken, becomes the subject of new considerations which focus on the new word, in relation to which the first word becomes a peripheral element. Therefore, the word is always absolute and always relative." 101 According to Hegel, philosophizing boiled down to the self-knowledge of the subject and ultimately was to lead to the development of the idea of the absolute in the knowing subject. For this reason, the philosophy of the Prussian thinker could be identified with a religion in which man believes in himself. ${ }^{102}$

What Hegel did in philosophy was then reformed by Feuerbach and Marx and successfully applied in politics. Marx stated that every ideology (including religion) is a "false consciousness" constantly deformed by historical and social class conditions. Hence the demand for a firm opposition to ideology, and above

99 A. R. Nowicki, Zarys dziejów, p. 51.

100 A. R. Nowicki, Teksty filozoficzne z punktu widzenia ich przekształcalności, ,Studia filozoficzne" 1975, no. 12 (121), p. 77-90.

${ }^{101}$ A. R. Nowicki, Współczesna filozofia włoska, p. 205.

${ }^{102}$ S. Kamiński, Jak filozofowano?, [in:] S. Kamiński, Jak filozofować? Studia z metodologii filozofii klasycznej, Lublin 1989, p. 39. 
all, religion. ${ }^{103}$ According to Nowicki, Federico Lombardi - an Italian materialist aptly described the genesis of Marxist criticism of religion. Hegel believed that a concept that does not take into account all its reality, and therefore its historical development, does not really describe reality. That is why the concepts contained not only the content but also the history of all their dialectical development. For this reason, the Prussian philosopher recognized as real only that development which had already ended. In this way, Hegel announced the end of history, philosophy and religion. Marx opposed the actions of the proletariat with the thoughts of Hegel. He considered the present and future (and thus in a way the twentieth century) philosophy of materialism as a time in which many doctrines (including religions), which until now were considered dogmatic and absolute, would be exposed as ideologies, and thus false projections of the practical interests and human motives falsely elevated to a "philosophical heaven". ${ }^{104}$ Louis Feuerbach and Karl Marx, included in the so-called "Hegelian left" introduced a new dialectical method by changing the Hegelian method. It would help in the inductive investigation of the development of the most general laws of the nature sciences, individual human thought and social thought. The change introduced by the two materialists mentioned above was, according to Nowicki, the funeral of "of what is 'dead' in Hegel's system, and therefore what is metaphysical, theological and theologizing." 105

The dialectical method can be philosophically fascinating, because, as Henri Bergson wrote, "One can only know and understand to some extent that which can be discovered by oneself." 106 By applying the dialectical method consistently, even irrevocable truths are questioned. "On the one hand, if it is true that you cannot reveal the truth other than by interpreting and defining it, then it is also true that this interpretation and formulation is just a revelation of the truth, so it is not something other than the truth, but it is the truth itself as something possessed personally. [...] It is [truth - ed. B. K.] just possessing the truth and the more authentic it is, the more personal and manifold it is" 107 The whole idea of atheistic criticism of religion is based on the understanding that the concept of the dialectic criticism of a view is not synonymous with its simple negation. A simple negation would be a mere shift away, a rejection of the view in its entirety; leaving it alone and risking its "return" in a few years. Dialectic criticism of religion was ultimately meant to shatter it. This was to be done through the mental "absorption and annihilation" of criticized views. ${ }^{108}$ This "absorption" in the Marxist nomenclature is called "dialectical affirmation". In the

\footnotetext{
${ }^{103}$ A. R. Nowicki, Współczesna filozofia włoska, p. 123.

${ }^{104}$ A. R. Nowicki, Współczesna filozofia włoska, p. 128-131.

${ }^{105}$ A. R. Nowicki, Współczesna filozofia włoska, p. 195.

${ }^{106}$ H. Bergson, Myśl i ruch. Dusza i ciało, Warsaw 1963, p. 94.

${ }^{107}$ L. Payerson, Prawda a interpretacja. Nie mistycyzm niewyrażalnego lecz ontologia niewyczerpalnego, [in:] A. R. Nowicki, Współczesna filozofia włoska, Warsaw 1977, p. $205-$ 206.

${ }^{108}$ A. R. Nowicki, Zarys dziejów, p. 51.
} 
case of religion, this consists in transforming religious content in such a way that it can be accepted by the mind of an atheist. An operation on religious views would be necessary. It would have to be an "amputation" or "extraction" of everything that is supernatural, thus, reducing religion to a natural or social phenomenon. Believers would have to assume that "primordial atheism" existed before primitive figures of religion such as magic and animism appeared, and consequently religion itself. ${ }^{109}$

And so, the criticism of religion begins with the very ideological mark that attempts to define it. When it comes to religion, it has not had any supernatural connotations since the very beginning. Ideologically indifferent definitions of religion are used as an argument by atheists in such a way that those compatible with atheism are treated as objective, while those containing references to the existence of God are rejected as indifferent and biased. Attaching labels is usually undesirable because most often they ignore some features and causes of a given defined phenomenon that become subjectively determined. ${ }^{110}$

Religion, according to atheists, did not have supernatural connotations at the beginning. The ancient Romans used the word religion to describe the diligent observance of required rites. ${ }^{111}$ They derived the term from the Latin word meaning "to bind". ${ }^{12}$ Only Christian theologians, such as St. Thomas Aquinas, understood religion a little differently. Thomas treated it as part of the virtue of justice, consisting in worshiping God within the framework of justice defined as suum cuique reddere, that is, giving everyone what was owed to him. ${ }^{113}$ Zofia Zdybicka, in the spirit of Christian philosophy, defined religion as "[t]he personal relationship of man to a personal God whom man considers to be the final source of his existence and the highest good that gives meaning to life." 114 Schleiermacher, who had a positive attitude towards religion, saw in it a certain expression of feelings, especially the feeling of an absolute dependence on the Universe. ${ }^{115}$ Atheists, for understandable reasons, tend to return to a naturalistic or sociological understanding of religion. Therefore, according to the definition of religion developed by Friedrich Engels, religion is "the fantastic reflection in human minds of those external forces which control their life, a reflection in which terrestrial forces assume the form of supernatural forces." ${ }^{\prime 16}$ The critic of religion should not focus on the topic of its natural origins. The dialectics which begin from the critical affirmation of religion by atheistic views is supposed to result in the dying out of religion. However, this process will not end with the com-

\footnotetext{
${ }^{109}$ A. R. Nowicki, Zarys dziejów, p. 45.

110 A. R. Nowicki, Zarys dziejów, p. 34.

111 Cicero, Pisma filozoficzne, t. 1, Warsaw 1960, p. 72; see: P. Moskal, Religia i prawda, p. 20.

112 Re-ligere means to bind again.

113 St. Thomas Aquinas, Summ Theologica, I-II, q. 81.

114 Z. Zdybicka, Czlowiek i religia, Lublin 2006, p. 299.

${ }^{115}$ A. R. Nowicki, Zarys dziejów, p. 18.

116 F. Engels, Anty-Dühring, [in:] K. Marks, F. Engels, Dzieła, Warsaw 1972, p. 352.
} 
plete extinction of all religious activity. Although there are visions of a non-religious future of Europe, according to the spirit of dialectics and evolution, religion may take the form of quasi-religion as a "residual organ". It could be, for example, a cult of reason or some other form of "spirituality without God". ${ }^{117}$

\section{Summary}

The purpose of this modest article was to show selected methods of the criticism of religion used by modern atheists. Contemporary atheism, called the "new" atheism, is one form of the negation of God's existence. It is based on criticism directed against the followers of various religions based on the assumption of the non-existence of God and focused on the final liquidation of all forms of religion. The multifaceted criticism of religion, especially Christian, is associated with the multifaceted phenomenon of religion itself and the multitude of possible points of view about it. This criticism focuses on the object of religion, which is usually the object to which the cult is directed. It consists mainly in using the integrated method to illuminate the natural or social foundation of religion. In this spirit it is understood as an element of culture that emphasizes a selected part of material reality and "consecrates" it with the help of a supernatural halo and a sacred conceptual apparatus. The reason for choosing the object of worship and its sanctification are the psychological mechanisms of fear and fascination, which most often surrounds this not fully understood part of reality. According to atheists, the use of the mechanism described here causes a change in social relations consisting of a division and mutual opposition of small groups of people being closly related to the object of religion and larger groups that are not bound so strongly with the object of worship. This mutual opposition becomes a "good" basis for manipulation and social engineering.

Atheists, however, come to the conclusion that the criticism of religion outlined above is not sufficient for its final destruction and displacement as a socially harmful phenomenon. In order to achieve that purpose, they propose applying the dialectical method created by Hegel and reformed by Feuerbach and Marx. This method is based on dialectical affirmation, or "absorbing" criticized ideology, and religion is recognized as such. This "absorption" consists in transferring religious doctrines and views from a supernatural and sacred context into a context free from this type of ideological baggage. Hence, the atheist adopts the concept of religion devoid of any spiritual element. It is thus critically negated. An example of a dialectical negation is Friedrich Engels' theory of religion. Putting the concept of religion in an atheistic context will not cause its complete disappearance but will result in a post-religious synthesis in the form of new forms of worship and spirituality.

The modest size of this article does not allow for more attention to be given to this commonly used, dialectical critique of religion described above. I believe that

$\overline{117}$ A. R. Nowicki, Zarys dziejów, p. 47. 
this is an issue that requires further research. It can and should therefore result in subsequent articles and studies of the issue raised here.

\section{BIBLIOGRAPHY}

Bergson H., Myśl i ruch. Dusza i ciało, trans. K. Błeszyński, P. Beylin, Warsaw 1963. Bocheński J., Logika religii, thum. autora, [in:] J. Bocheński, Dzieła zebrane, t. 6, Religia, Kraków 1995, p. 23-122.

Cicero, Pisma filozoficzne, t. 1, trans. W. Kornatowski, Warsaw 1960.

Descartes R., Rozprawa o metodzie, tłum. Tadeusz Boy-Żeleński, Warsaw 2016.

Engels F., Anty-Dühring, [in:] K. Marks, F. Engels, Dzieła, Warsaw 1972, p. 303393.

Górny G., Rosikoń J., Tajemnice Fatimy. Największy sekret XX wieku, Warsaw 2016.

Gutowski P., Nauki filozoficzne a nowy ateizm, [in:] Nauki przyrodnicze a nowy ateizm, M. Słomka (ed.), Lublin 2012, p. 7-45.

Heller M., Niekricz A., Utopia u władzy, trans. A. Miętkowski, London 1985.

Kamiński S., Jak filozofować? Studia z metodologii filozofii klasycznej, Lublin 1989.

Kowalczyk S., Filozofia Boga, Lublin 2001.

Payerson L., Prawda a interpretacja. Nie mistycyzm niewyrażalnego lecz ontologia niewyczerpalnego, trans. A. R. Nowicki, [in:] L. Payerson, Wspótczesna filozofia wtoska, Warsaw 1977, p. 205-206.

Tindal-Robertson T., Fatima, Rosja i Jan Pawet II. W jaki sposób Maryja przyczynita się do wyzwolenia Rosji spod marksistowskiego ateizmu 13 maja 1981 - 25 grudnia 1991, trans. W. Łaszewski, Warsaw 1995.

Mirari S., How Dialogue is done? A Review of Michael Novak's No One sees God. The Dark Night of Atheists and Believers, "National Catholic Register" 2 (2016), p. 1-2.

Moskal P., Religia i prawda, Lublin 2008.

Nowicki A. R., Teksty filozoficzne z punktu widzenia ich przekształcalności, „Studia filozoficzne" 1975, no 12 (121), p. 77-90.

Nowicki A. R., Uczeń Twardowskiego Władysław Witwicki, Katowice 1983.

Nowicki A. R., Vanini, Warsaw 1987.

Nowicki A. R., Współczesna filozofia włoska, Warsaw 1977.

Nowicki A. R., Zarys dziejów krytyki religii. Starożytność, Warsaw 1986.

Novak M., No One sees God. The Dark Night of Atheists and Believers, New York 2008.

Thomas Aquinas St., Summa Theologica, Trans. P. Bełch i inn., London 1975-1998. 
Wojtysiak J., Filozofia i życie, Kraków 2007.

Zatwardnicki S., Ateizm urojony, Kraków 2014.

Zdybicka Z., Człowiek i religia, Lublin 2006.

\section{Summary}

A contemporary so-called "New Atheism” is one of the many ways the existence of God is denied. It is based on criticism directed against the followers of various religions. This criticism focuses on the object of religion to which the cult is directed. It is mainly about illuminating the natural or social foundation of religion. To annihilate religion, atheists postulate subjecting it to dialectical criticism developed by Karl Marx. This criticism of the concept of religion, although it will not make it disappear completely, will result in a post-religious synthesis which will appear in new forms of worship and spirituality.

Key words: atheism, religion, critics, dialectics, materialism

\section{O ateistycznej krytyce religii}

\section{Streszczenie}

Współczesny ateizm nazywany „nowym” jest jedną z form negacji istnienia Boga. Polega on na krytyce kierowanej przeciwko wyznawcom różnych religii. Ta krytyka skupia się na przedmiocie religii, ku któremu skierowany jest kult. Polega ona w głównej mierze na tym, żeby naświetlić naturalny lub społeczny fundament religii. Aby doprowadzić do unicestwienia religii, ateiści postulują poddanie jej krytyce dialektycznej opracowanej przez Karola Marksa. Ta krytyka pojęcia religii, chociaż nie sprawi jej całkowitego zaniku, ale zaowocuje post-religijną syntezą $\mathrm{w}$ postaci nowych form kultu i duchowości.

Słowa klucze: ateizm, religia, krytyka, dialektyka, materializm 